\title{
Letting my daughter go
}

Stephanie Nimmo's daughter, Daisy, was born with a life limiting condition and died in January 2017. On the anniversary of her loss, Stephanie reflects on how working with health professionals enabled Daisy to enjoy her life and have a peaceful, dignified death

\section{Stephanie Nimmo}

I always knew Daisy would die before reaching adulthood. She was my fourth child, born prematurely in December 2004 with a severe form of rare genetic condition called Costello syndrome. Daisy required complex care, but every decision about her care was made on the basis of improving the quality of her life, which meant helping her do the things she loved, such as being at home with her family, going to school, and playing with friends.

\section{Staying out of hospital}

I was trained to undertake most of her care, including setting up her parenteral nutrition and additional fluids, administering multiple daily intravenous infusions, and inserting catheters into her Mitrofanoff stoma. When possible, outpatient appointments were conducted by phone or without Daisy present. To minimise emergency hospital admissions and stays, the emergency department and children's ward had protocols specially written for her. A member of the palliative care team had access to her notes 24/7 and Daisy's main consultant wrote a letter confirming that I was competent to manage her care at home once she was stable.

\section{Working together}

Daisy had been under hospice care since she was six months old, and was referred to the paediatric palliative care team for symptom management when she was seven.

For children living with unpredictable complex conditions there has to be a good and early relationship with palliative care services to make plans and be able to change plans.

Her palliative consultant was able to help join up care between teams, and would often attend outpatient appointments with me. This was important because although I was Daisy's advocate and an expert on her daily care, I also needed precious time to be her mum.

\section{Letting Daisy go}

In early January 2017 Daisy was admitted to hospital with an infection. She had celebrated her 12th birthday a few weeks previously.

As sepsis took hold, Daisy was taken to intensive care and intubated. I saw she was closing down. It was time to let her go.

The most important thing for me now was to give Daisy dignity in death. I had hoped that we could transfer her to home or hospice for a compassionate extubation but she was too unstable. The last thing I wanted was for her to die in an ambulance in the middle of London.

I was offered the chance to move her to a private room for her final moments, but I did not want her disturbed any more. We pulled the curtains around, had the lights dimmed and played music. Patients were moved temporarily so we had no strangers around us.

A team of familiar nurses and a doctor kept a respectful distance as they took out lines, muted alarms, and prepared to extubate Daisy. When the ventilator was switched off they retreated from the bed and waited behind the curtains. Daisy's three siblings and I held her hand and sang to her as she took her last breaths.

\section{Living with loss}

That evening we brought Daisy home. Our palliative nurse liaised with the hospice and funeral directors to organise this, and the hospice at home nurse set up a special cold blanket on Daisy's bed. We also spent time at the hospice where Daisy could be visited by friends and family. A little girl with her family again—not a patient.

A year on, I miss Daisy desperately. When she died I felt that not only had I lost my child, I had lost my role, my purpose. I miss our medical teams, they were so much part of our life. Together, we gave Daisy 12 years of life, more than we had ever hoped for when she was born. 
What you need to know

- When children with complex needs have multidisciplinary teams looking after them someone needs to coordinate care.

- Start end of life planning conversations early so that the families have ownership of decisions when the time comes.

- Allowing families to have private time with their children at the moment of death is important.

Education into practice

- How might you talk to families of children who are life limited about the care they want for the child after death? What do you need to know, and what does the family need to know?

- How can communication between teams be coordinated to lift the burden from parents?

- Routinely offer a cold cot or a cold blanket within four to six hours of death. Consider how the child might be transported from the ward to their home or children's hospice after death, rather than via the mortuary.

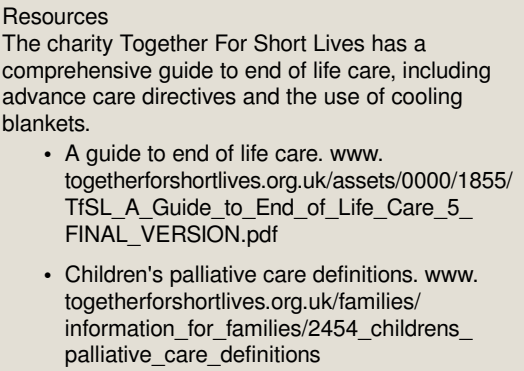

A guide to end of life care. www. togetherforshortlives.org.uk/assets/0000/1855/ TfSL_A_Guide_to_End_of_Life_Care_5 FINAL_VERSION.pdf

- Children's palliative care definitions. www. togetherforshortlives.org.uk/families/ information_for_families/2454_childrens palliative care definitions

Competing interests: I have read and understood BMJ policy on declaration of interests and declare the following: none.

Published by the BMJ Publishing Group Limited. For permission to use (where not already granted under a licence) please go to http://group.bmj.com/group/rights-licensing/ permissions 